\title{
The Effects of Foreign Direct Investment, Trade, Aid, Remittances and Tourism on Welfare under Terrorism and Militancy
}

\author{
"Olaniyi Evans ${ }^{1}$ \\ Ikechukwu Kelikume ${ }^{1}$ \\ 'Lagos Business School,Pinl-Itlintic Lniversity, Liagos, Nigereria \\ The purpose of this study was to determine the effects of \\ Foreign Direct Investment (FDI), trade, aid, remittances and \\ tourism on welfare under terrorism and militancy. Using Nigeria \\ as a case study for the period from 1980 to 2016, this study \\ utilized autoregressive distributed lag (ARDL) bounds testing \\ approach and the Cobb-Douglas production function. The empirical \\ findings showed that, in the short-run, FDI, trade, aid, \\ remittances and tourism had positive significant effects on \\ welfare, even under terrorism and militancy. However, in the \\ long run, only aid and remittances had significant effects while \\ FDI, trade and tourism were insignificant. In other words, FDI, \\ trade and tourist inflows were repressed as a result of the \\ presence of terrorism and militancy in the long-run, meaning \\ that they could not thrive in tensed and insecure environments. \\ Surprisingly, despite the presence of militancy and terrorism, \\ in the long-run, aid and remittances still had significant \\ effects on welfare. The findings also showed that terrorism and \\ militancy had significant negative effects on welfare both in \\ the short and long run. In conclusion, terrorism and militancy \\ not only undermined FDI, trade and tourism, but also led to a \\ significant decline in welfare. \\ Keywords: Foreign direct investment, trade, aid, remittances, \\ tourism, terrorism, militancy \\ JEL:D60, E27, H54, I31
}

Many developing countries such as Nigeria have undertaken programs of external economic liberalization in recent decades (See Wacziarg and Welch, 2008; Bascom, 2016; Picciotto and Mayne, 2016; Bhagwati, 2017; Dzorgbo, 2017; Salacuse, 2017; Seteolu, 2017; Blanton, Early and Peksen, 2018; Haggard and Kaufman, 2018; Njinyah, 2018; Shalev, 2018). In 1960, only 22 percent of all countries had such openness, but by 2016, 56 percent of countries were open to international trade (World Bank, 2018). Indeed, in recent decades, countries are not only open to trade, but also to other international flows such as foreign direct investment (FDI), aid, remittances and tourism. The increasing openness has been fueled by the desire of many developing countries to harness not only the growth effects but also the welfare benefits of such foreign flows (See Klobodu and Adams, 2016; Magombeyi and Odhiambo, 2017; Evans, 2018).

Manuscript received March 24, 2018; revised July 12, 2018; accepted August 15, 2018. @ The Author(s); CC BY-NC; Licensee IJMESS

*Corresponding author: olaniyievans@gmail.com 
Particularly, welfare is the level of prosperity and quality of living standards in an economy (Lawn, 2003; Pigou, 2017). The literature shows that international flows such as FDI, trade, aid, remittances and tourism are essential for welfare in any country (Ordu, 2017; Evans, 2018; Saeed and Syed, 2018). FDI, trade, aid, remittances and tourist flows are needed to augment the insignificant domestic sources of income especially in poor developing countries such as Nigeria. For example, FDI creates employment opportunities and increases welfare by enabling build-up of physical capital, developing productive capacity, enhancing skills of local labor through technology transfer and managerial know-how, and integrating the domestic economy with the global economy (Liang, 2017; Melane-Lavado, Álvarez-Herranz and González-González, 2017). Similarly, international trade, the exchange of goods and services among various countries and regions, gives domestic firms more experience in producing for foreign markets. Over time, domestic firms gain competitive advantage in global trade.

The objective of foreign aid is reduction of poverty, or improving the welfare and living conditions of the poor. In many countries, aid is used to finance spending that improves the welfare of the poor, such as universal access to health care and primary education (Gomanee et al., 2003). Similarly, tourism receipts are regarded as a major source of foreign exchange and a key source of economic growth (Blake, 2000; Nowak, Sahli and Sgro, 2003; Adeola, Boso and Evans, 2017). Tourism complements the foreign exchange already derived from trade and sometimes finances the imports of capital goods necessary for the manufacturing sector also regarded as a mechanism for generating increased income and employment both in the formal and informal sectors of the economy (Nowak et al., 2003). Also, remittances are important for any developing economy. Indeed, the significance of remittance inflows into Nigeria is evidenced by the explosion of money transfer institutions (both formal and informal) and the swift growth in remittances (Fonta, Onyukwu and Nwosu, 2011).

Though these international inflows are important for a developing country, they seem to have been undermined in Nigeria where there are grave problems of militancy and terrorism. For example, the current Niger Delta militancy, which first arose in the early 1990s over tensions between foreign oil corporations and Niger Delta's minority ethnic groups who felt they were being exploited, has hit the Nigerian oil 


\section{Evans \& Kelikume}

industry with violence, kidnappings and piracy from 2004 to-date. In February 2016, the Niger Delta militants bombed a pipeline belonging to Shell Petroleum Development Corporation (a Royal Dutch Shell subsidiary to the Shell Forcados export terminal). As a result, on May 11, Shell shut down its Bonny oil facility, and then stopped both production and imports. Chevron's Escravos GTL facility and ExxonMobil's Qua Iboe were similarly shut down. Consequently, Nigerian oil production was drastically reduced to 300,000 barrels per day. In the same vein, terrorism has posed a fundamental threat to the safety and security of Nigerians. For example, in July 2017, the Nigerian National Petroleum Corporation (NNPC) oil exploration team was ambushed in northeast Nigeria (in the Magumeri area of Borno state) by Boko Haram. As a result, more than 50 people were killed. The attack emphasized the persistent threat posed by terrorism, which has left more than 2.6 million homeless and 20,000 dead since 2009.

There are several motivations for this study. Markedly, key international flows such as FDI, trade, aid and tourist flows have nosedived since terrorism and militancy began in Nigeria (see Figure 1, Appendix-I), meaning that terrorism and militancy have likely undermined the effects of FDI, trade, aid and tourist flows on welfare. A number of questions therefore arose from the foregoing. For example, what are the impacts of FDI, trade, aid, remittances and tourism on welfare under terrorism and militancy? Are there significant differences in the welfare effects in the short- and long-run? These are weighty questions, the answers to which will provide improved insights into the welfare implications of FDI, trade, aid, remittances and tourist inflows into Nigeria and other developing countries under terrorism and militancy. However, the effects of FDI, trade, aid, remittances, tourism, terrorism or militancy on welfare was studied by few scholars and the results are conflicting and disparate (e.g., Fonta et al. 2011; Shah, Hasnat and Ahmad, 2016; Abonyi and Ezeh, 2017; Evans, 2018; Saeed and Syed, 2018). Moreover, very few of the studies have investigated the short- and long-run effects. Further, only few studies in the literature have considered Nigeria (e.g., Osemwengie and Oriakhi, 2012; Ordu, 2017; Evans, 2018), even though FDI, trade, aid, and tourist inflows to Nigeria have considerably reduced since the instigation of terrorism and militancy in the country.

To fill this gap and to quantify the above concerns, this study contributes to the literature by building a time series data set and estimating the impacts of FDI, trade, aid, remittances and tourism on welfare under 
terrorism and militancy using autoregressive distributed lag (ARDL) model consistent with Pesaran and Shin (1999) and Pesaran, Shin and Smith (2001) to account for short- and long-run effects. The focus and contribution of this study to the literature is therefore about how terrorism and militancy interacts with the effects of FDI, trade, aid, remittances and tourism on welfare, and as a result significantly influence welfare. This study therefore contributes to the empirical literature on the effects of FDI, trade, aid, remittances, tourism, terrorism and militancy on welfare in less studied, insecure emerging economies such as Nigeria. The insights from the study would be helpful to policymakers, so that they could better formulate policies to attract FDI, trade, aid, remittances and tourist inflows in insecure environments. It could also offer useful insights on re-evaluation of terrorism and militancy. Indeed, the present paper is the first paper as per our knowledge to study the effects of FDI, trade, aid, remittances and tourism on welfare under terrorism and militancy, especially for the case of Nigeria. No other study in the literature has filled this gap yet.

The rest of the paper is structured as follows: Section 2 covers related theories and previous literature. Section 3 discusses the method and data. Section 4 presents empirical results, discussion and implications. The policy implications of the results and directions for further research are presented in section 5.

\section{LITERATURE REVIEW}

The path-breaking Harrod-Domar model $(1939,1946)$ remains the fundamental reference in the economics of investment, and it highlights the significance of determining the rate of investment, needed to achieve a certain rate of economic growth (Evans, 2018). In the same vein, the role of foreign investment (in the form

of FDI) in economic growth has been recognized as key in the literature (See Gunby, Jin and Reed, 2017; Olagbaju and Akinlo, 2018; Bunte et al., 2018; Sharma, Rishad and Gupta, 2018). However, this role of FDI in economic growth is highly controversial. The proponents of FDI argued that FDI augments capital formation in the host country and thereby promotes economic growth (e.g., Tang, Selvanathan and Selvanathan, 2008; Lean and Tan, 2011). On the contrary, opponents of FDI argued that FDI has an adverse effect on growth (e.g., Akinlo, 2004; Duasa, 2007). Remarkably, the existing literature is much concentrated on investigating the broad effects of FDI on growth. The contribution of FDI to welfare has attracted very little attention, in general. 


\section{Evans \& Kelikume}

Similarly, while empirical studies on the effects of trade on growth outcomes has received extensive attention in the literature (e.g., Theodorou, 2017; Grossman and Helpman, 2018; Perkins, Castaño and Montemayor, 2018), the welfare effects remain under-researched (e.g., Bhagwati, 2018; Behling, 2018). For example, Dollar and Kraay (2003) provided evidence of a strong effect of trade on growth. Using a dynamic panel framework and three different indicators of liberalization, Greenaway, Morgan, and Wright (2002) found that trade liberalization influences growth, albeit with a lag. Their evidence points to a J-curve type response. Wacziarg and Welch (2008: 187) showed that "over the 1950-98 period, countries that liberalized their trade regimes experienced average annual growth rates that were about 1.5 percentage points higher than before liberalization. Post-liberalization investment rates rose 1.5-2.0 percentage points, confirming past findings that liberalization fosters growth in part through its effect on physical capital accumulation". Trade liberalization raised average trade to GDP ratio by 5 percentage points, meaning that trade liberalization raised the level of openness. However, these average effects mask the differences across countries. In fact, Okodua and Alege (2014) found evidence that a policy of full or partial trade liberalization has mixed welfare implications for Nigerian households in the short-run.

Similarly, the effects of aid have been of great interest to policy makers and academics (e.g., Manuelli and Vizcaino, 2017; Savun and Tirone, 2017; Dreher, Lang and Ziaja, 2018). However, very few studies have looked at the relationship between aid and welfare. For example, Burnside and Dollar (2000) found that aid has a positive effect on growth in developing countries with good policies but has insignificant effect in the presence of poor policies. Gomanee et al. (2003) found that pro-poor public expenditure is linked with improved levels of welfare. They also found evidence that aid is linked with improved welfare because aid finances pro-poor spending, meaning that aid can improve the welfare of the poor. Djajić (2006: 105) shows that donor country's aid is provided to discourage the poor from emigrating: "The extent to which it achieves this objective is shown to be an important factor determining the welfare implications of aid for every type of household residing in the economy". Agarwal, Hazari and Xindun (2010) examine the effects of aid and corruption on the welfare of different classes in a receiving economy using a general equilibrium model. They found that, under certain conditions, aid immiserizes the poor. 
Also, the contribution of remittance inflows to welfare has attracted very little attention in general (e.g., Ajaero, Nzeadibe, Obisie-Nmehielle and Ike, 2018; Cuong and Linh, 2018; Kangmennaang, Bezner-Kerr and Luginaah, 2018). The literature is much focused on investigating the broad effects of remittances on growth and poverty reduction (e.g., Wadood and Hossain, 2017; Apergis and Cooray, 2018; Bahadir, Chatterjee and Lebesmuehlbacher, 2018; Li and Wang, 2017; Petreski et al., 2018). For example, Yang and Martinez (2005) found, for Philippines, that remittance inflows lead to poverty reduction in migrants' origin households. Lidley (2006) also found that remittances inflows to a Somalian city improved their economic status and access to education. Adams and Page (2003), for a sample of 74 low and middle-income developing countries, showed that remittances had a strong statistical effect on poverty reduction in the developing world. Fonta et al. (2011) found that household poverty declines across all the Nigerian geopolitical zones, by sex and locality as a result of remittance inflows. For example, Fonta et al. (2011: 140) found that "with remittances, household poverty falls from 0.35 to 0.30 in the South-South region, 0.27 to 0.22 in the SouthEast region and 0.43 to 0.36 in the South-West region. Poverty also declines from 0.67 to 0.60 in the NorthCentral region, 0.72 to 0.66 in North-East and from 0.71 to 0.66 in the North-West regions". Similarly, they found that increase in remittance inflows reduce income inequality more in urban areas than in rural areas.

Similarly, beyond the literature on the economic impacts of tourism (e.g., Raza and Shah, 2017; Gupta and Dutta, 2018; Njoya and Seetaram, 2018), relatively little empirical research examined the effects of tourism on welfare (e.g., Wardana, Adnyani and Ekawati, 2017; Zhang and Zhang, 2018). For example, Blake (2000) found that the effects of a 10 percent increase in tourism would increase welfare by 28 billion Pesetas (0.05\% of GDP) over the long-term in Spain. According to Gursoy, Jurowski, and Uysal (2002), tourism development certainly changes the residents' quality of life. Nowak et al. (2003) examined the effects of tourism boom on structural adjustment, commodity and factor prices, and resident welfare. They found that the tourist boom can "immiserize" residents because of (i) a positive effect due to an increase in the relative price of the non-traded good; (ii) a negative effect due to an efficiency loss in the presence of increasing returns in manufacturing. For 50 Spanish provinces, Urtasun and Gutiérrez (2006) showed the existence of carrying capacity frontiers that tourist destinations can sustain without damaging the socio, 


\section{Evans \& Kelikume}

cultural, economic or environmental systems of the communities they belong.

Terrorism is the illegal use of violence or terror in the quest for political aims while militancy is the use of aggressive or violent methods in support of a social or political cause (Peterson, 2001; Droogan, 2018; Ganaie, 2018). The existing literature shows that such acts of violence and terror have high socio, economic, and physical cost (See Ogbozor, 2018; Sirgy, Joshanloo and Estes, 2018; Stankov et al., 2018). The direct destruction of infrastructure and the consequent high demand for security and the rise in operating costs can lead to pulling out of FDI by countries and companies, and lead to consequent loss in GDP and welfare (Enders and Sandler, 2008; Frey, Luechinger and Stutzer, 2007).

An increasing number of studies examined the effects of acts of terror on an economy (e.g., Shah et al., 2016; Evans, 2018; Saeed and Syed, 2018). For example, Bandyopadhyay, Sandler and Younas (2011), using a panel of 78 countries for the 1984-2008 period, found that terrorism has a significantly adverse effect on FDI as a share of GDP. Shah et al. (2016: 216) investigated the short-and long-run effects of human cost of terror on private consumption, private investment and GDP in Pakistan. The evidence showed that "the long-run association between the human cost of terror, GDP, private consumption and private investment and suggest that the human cost of terror adversely affects GDP and private investment, and positively influences private consumption in the long-run. Furthermore, the results in the study revealed that the human cost of terror negatively affects GDP and private investment and increases private consumption in the shortrun". The overall findings largely showed that the human cost of terror distorts private consumption, depresses investment as well as constrains growth both in the short- and long-run.

Evans (2018) investigated the effects of FDI, domestic investment and infrastructure on welfare in Nigeria under terrorism, militancy and policy uncertainty. While FDI and domestic investment were shown to have positive significant effects on welfare, the estimates were repressed as a result of the presence of terrorism, militancy and policy uncertainty. While infrastructure has insignificant positive effects on welfare, the effects become more insignificant under terrorism, militancy and policy uncertainty. Evans (2018) also showed that terrorism, militancy and policy uncertainty have significant negative effects on welfare. In a nutshell, terrorism and militancy not only breed uncertainties but also lead to damaged infrastructure which undermines welfare. 
It is worth noting that while empirical studies on the growth effects of FDI, trade, aid, remittances, tourism, terrorism and militancy have received extensive attention in the literature, the welfare effects remain underresearched. Filling this gap is essential especially because "an increase in the rate of growth does not always imply an increase in welfare" (Reis, 2001: 411). Further, in the few studies that have considered the welfare effects, the results are conflicting and disparate, and very few of the studies have considered the short- and long-run effects. Moreover, very few studies have looked at the welfare effects in Nigeria, even though FDI, trade, aid, and tourist inflows to Nigeria have drastically reduced since the incipience of terrorism and militancy in the country.

\section{METHODOLOGY}

\section{-Data}

This study employed annual data between 1980 and 2016. Data on net inflows of FDI (\% of GDP), net official development assistance and official aid received, trade (\% of GDP), international tourist arrivals, GDP per capita, gross capital formation (\% of GDP) secondary school enrollment, personal remittances received and real effective exchange rate were sourced from World Bank (World Bank, 2018) world development indicators database.

\section{-Model}

Although, there are many non-linear econometric models, the Cobb-Douglas production function of the following form was considered (Cobb and Douglas, 1928):

$Y=A K^{\alpha} L^{\beta}$

where "Y" is total quantity, "K" is capital, "A" is total factor productivity and $\mathrm{L}$ is labor. $\alpha$ and $\beta$ are the elasticities of capital and labor, respectively.

The logarithmic form is:

$\ln Y=\ln A+\alpha \ln K+\beta \ln L$

In line with Evans (2018), equation 2 can be applied to welfare as follows,

$$
G d p c_{t}=\omega_{0}+\omega_{1} G c f_{t}+\omega_{2} \operatorname{Ser}_{t}
$$




\section{Evans \& Kelikume}

where "Gdpc" is the GDP per capita (proxy for welfare). In the literature, GDP per capita is a popular proxy for welfare (Arora, 2013). "Gcf" is gross capital formation as a share of GDP (proxy for domestic investment). Gross capital formation as a share of GDP is the proxy for domestic investment in many studies in the literature (e.g., Carstensen and Toubal, 2004; Wang, 2009). "Ser" is secondary school enrollment (proxy for skilled labor). Secondary school enrollment is a proxy for skilled labor in labor economics (e.g., Noorbakhsh, Paloni and Youssef, 2001; Ebenstein et al., 2014).

In order to achieve the objectives of the study, FDI, trade, foreign aid, remittances, tourist arrivals, terrorism and militancy were added to the model:

$$
\begin{gathered}
\text { Gdpc } c_{t}=\omega_{0}+\omega_{1} \text { Gcf }_{t}+\omega_{2} \text { Ser }_{t}+\omega_{3} \text { Fdi }+\omega_{4} \text { Trade }_{t}+\omega_{5} \text { Aid }_{t}+\omega_{6} \text { Remit }+\omega_{7} \text { Tourism }_{t} \\
+\omega_{8} \text { Excr }_{t}+\omega_{9} \text { Ter }_{t}+\omega_{10} \text { Mil }_{t}+\varepsilon_{t}
\end{gathered}
$$

Where "Fdi" is net inflows of FDI (\% of GDP); and "Trade" is trade (\% of GDP). "Aid" is net official development assistance and official aid received; "Tourism" is international tourist arrivals; "Remit" is personal remittances received; and "Excr" is real effective exchange rate. "Ter" is terrorism (dummy variable that takes 1 in the years of terrorist attacks and 0 otherwise); and "Mil" is militancy (dummy variable that takes 1 in the years of militancy and 0 otherwise). Terrorism (Ter) and militancy (Mil) are moderating variables.

ARDL bounds testing approach is used in this study, consistent with Pesaran, Shin and Smith (2001). The ARDL bounds testing approach has a number of merits: (i) it can measure both short and long-run effects at once (Bentzen and Engsted, 2001); it is appropriate even for small samples (Ghatak and Siddiki, 2001); and (iii) it is valid even when the variables are a mix of $I(0)$ or $I(1)$.

In the ARDL estimation, a two-step procedure is followed. The ARDL bounds test for the joint significance of the lagged level variables is the first procedure. To perform the bounds test, equation 4 is remodeled as a conditional ARDL error correction model as follows: 


$$
\begin{aligned}
& \Delta G d p c_{t}=\omega_{0}+\lambda_{1} G d p c_{t-1}+\lambda_{1} G c f_{t-1}+\lambda_{2} \operatorname{Ser}_{t-1}+\lambda_{3} F d i_{t-1}+\lambda_{4} \text { Trade }_{t-1}+\lambda_{5} \text { Aid }_{t-1}+\lambda_{6} \text { Pemit }_{t-1} \\
& +\lambda_{7} \text { Tourtsm }_{t-1}+\lambda_{8} \text { Excr }_{t-1}+\lambda_{s} \text { Ter }_{t-1}+\lambda_{10} M u_{t-1}+\sum_{i=1}^{p} \alpha_{i} \Delta G d p c_{t-i} \\
& +\sum_{i=1}^{p} \beta_{i} \Delta G c f_{t-i}+\sum_{i=1}^{p} \gamma_{i} \Delta S e r_{t-i}+\sum_{i=1}^{p} \delta_{i} \Delta F d i_{t-i}+\sum_{i=1}^{p} \theta_{i} \Delta \operatorname{Tradg_{t-i}}+\sum_{i=1}^{p} \vartheta_{i} \Delta A i d_{t-i} \\
& +\sum_{i=1}^{p} \sigma_{i} \Delta \operatorname{Remit}_{t-i}+\sum_{i=1}^{p} \tau_{i} \Delta \text { Tourism }_{t-i}+\sum_{i=1}^{p} \varphi_{i} \Delta \text { Excr }_{t-i}+\sum_{i=1}^{p} \phi_{i} \Delta \operatorname{Ter}_{t-i} \\
& +\sum_{\mathrm{i}=1}^{p} \chi_{i} \Delta M i_{t-i}+\epsilon_{t}
\end{aligned}
$$

Where $a_{0}$ is a drift component and $\epsilon_{\mathrm{t}}$ is the white noise error. The coefficients of the lagged level variables $\left(\lambda_{1}\right.$ to $\left.\lambda_{10}\right)$ are the long-run multipliers while $\alpha \mathrm{i}, \beta_{i}, \gamma_{i}, \delta_{i}, \theta_{i}, \vartheta_{i}, \sigma_{i}, \tau_{i}, \varphi_{i}, \phi_{i}$ and $\chi_{i}$ represent the shortrun impacts on welfare (proxy by GDP per capita). The null hypothesis of no cointegration $\left(H_{0}: \lambda_{1}=\lambda_{1}=\lambda_{2}=\lambda_{3}=\lambda_{4}=\lambda_{5}=\lambda_{6}=\lambda_{7}=\lambda_{8}=\lambda_{9}=\lambda_{10}=0\right)$ is tested against the alternative hypothesis of co-integration $\left(H_{0}: \lambda_{1} \neq \lambda_{1} \neq \lambda_{2} \neq \lambda_{3} \neq \lambda_{4} \neq \lambda_{5} \neq \lambda_{6} \neq \lambda_{7} \neq \lambda_{8} \neq \lambda_{9} \neq \lambda_{10}=0\right)$ via f-statistic test. There are two asymptotic critical value bounds: the lower bound assumes that all regressors are $I(0)$ while the upper bound assumes that all are I(1). The null is rejected if the computed $f$ statistic is higher than the upper bound, thus suggesting co-integration (Pesaran and Pesaran, 1997; Evans, 2017).

The final procedure is the estimation of the long-run relationship and making relevant inferences about their values (Pesaran and Pesaran, 1997). This procedure involves two further steps: "The first stage involves selecting the orders of the lags based on Schwarz Bayesian Information Criteria (SBIC) or the Akaike Information Criteria (AIC). In the second step, the selected optimal ARDL model restricted to the lag structure defined in the first stage of the final ARDL process is then estimated including the short-run and error correction model" (see Tandrayen-Ragoobur, 2010: 11).

Constructing a lagged error correction term to represent the whole set of lagged level variables, the shortrun coefficients can be estimated as an error correction model which allows for long-run estimates as follows: 


\section{Evans \& Kelikume}

$$
\begin{aligned}
& \Delta G d p c_{t}=\kappa_{0}+\sum_{i=1}^{p} \kappa_{1} \Delta G d p c_{t-\tilde{i}} \\
& +\sum_{i=1}^{p} \kappa_{2} \Delta G c f_{t_{i}}+\sum_{i=1}^{p} \kappa_{3} \Delta \operatorname{Ser}_{t_{i}}+\sum_{i=1}^{p} \kappa_{4} \Delta F d i_{i}+\sum_{i=1}^{p} \kappa_{\bar{S}} \Delta \operatorname{Trade}_{\mathrm{t}_{i}} \\
& +\sum_{i=1}^{p} \kappa_{b} \Delta \text { Aid }_{t-1}+\sum_{i=1}^{p} \kappa_{i} \Delta \text { Remit }_{t-1}+\sum_{i=1}^{p} \kappa_{\mathrm{s}} \Delta \text { Tourism }_{t-1}+\sum_{i=1}^{p} \kappa_{y} \Delta E x \mathrm{e} \\
& +\sum_{i=1}^{p} \kappa_{10} \Delta T e r_{t-i}+\sum_{i=1}^{p} \kappa_{11} \Delta M i l_{t-i}+\kappa_{12} E c t_{i-1}+\mu_{t}
\end{aligned}
$$

Ect $t-1$ is the error correction term; ${ }^{\kappa_{12}}$ is the speed of adjustment. The other coefficients $\left(\kappa_{1}\right.$ to $\left.\kappa_{11}\right)$ are the short-run dynamics which force the model to converge to equilibrium.

\section{Empirical Analysis}

Before estimation of the model, it is appropriate to check the order of integration of the variables because most macroeconomic time series have unit root (Nelson and Plosser 1982; Adeola and Evans, 2017). This study therefore employs the Elliot, Rothenberg and Stock (ERS) point optimal unit root test which is more computationally robust than the popular unit root tests (e.g., Augmented Dickey-Fuller (1979) and PhillipsPerron (1988) tests) found in the literature. As shown in Table 1, the results of the ERS test show that some of the variables are stationary at $I(0)$ and others at $I(1)$. This is an indication that the variables are a mix of I(0) and I/1) which is appropriate for the ARDL approach.

Having confirmed the variables are a mix of $I(0)$ and $I(1)$, the ARDL bounds test is implemented as shown in Table 2. The calculated $f$-statistic $(f=9.26)$ is higher than the upper bound critical value at 1 percent level of significance. This is an indication that there is co-integration among the variables.

Using the Schwartz Criterion to select the appropriate lags of the ARDL, the short- and long-run coefficients are estimated. The co-integrating relationship among the variables support the use of an error correction model in investigating the short-run dynamics. Table 3 (see Appendix-II) shows the estimation results based on Schwartz Bayesian Criteria. In the short-run, capital formation (Gcf), skilled labor (Ser), FDI, trade, foreign aid, remittances (Remit) and tourism have positive and significant effects on welfare (Gdpc). 


\begin{tabular}{ccc}
\hline & $\mathbf{I}(\mathbf{0})$ & $\mathbf{I}(\mathbf{1})$ \\
\hline$G d p c$ & $1.23^{*}$ & $0.94^{*}$ \\
$G c f$ & 3.92 & $3.32^{* * *}$ \\
Ser & $2.32^{* *}$ & $0.22^{*}$ \\
$F d i$ & 24.31 & $3.08^{* * *}$ \\
Trade & $2.09 * *$ & $1.39^{*}$ \\
Aid & 10.84 & $2.63^{* *}$ \\
Remit & $2.72^{* *}$ & $1.94^{* *}$ \\
Tourism & 20.81 & $3.72^{* * *}$ \\
Excr & $3.51 * * *$ & $0.34^{*}$ \\
Ter & 5.23 & $1.16^{*}$ \\
Mil & 4.67 & $1.42 *$ \\
& $1 \%$ level & 1.87 \\
Test critical values: & $5 \%$ level & 2.97 \\
& $10 \%$ level & 3.91
\end{tabular}

Notes: $*$ significant at $1 \% ; * *$ significant at $5 \% ; * * *$ significant at $10 \%$

Lag length is selected using Spectral OLS AR based on SIC, maxlag=9

Table 1. Elliott-Rothenberg-Stock Unit Root Test

\begin{tabular}{lll}
\hline Test Statistic & Value & K \\
\hline & & \\
F-statistic & $9.26^{*}$ & 10
\end{tabular}

Critical Value Bounds

\begin{tabular}{lll} 
Significance & I(0) Bound & I(1) Bound \\
& & \\
$10 \%$ & 1.83 & 2.94 \\
$5 \%$ & 2.06 & 3.24 \\
$2.5 \%$ & 2.28 & 3.5 \\
$1 \%$ & 2.54 & 3.86 \\
\hline Notes: * significant at 1\%; Lag length selected by Schwarz Info Criterion
\end{tabular}

Table 2. ARDL Bounds Test

On the contrary, exchange rate $(E x c r)$, terrorism (Ter) and militancy (Mi) have negative and significant effects on welfare $(G d p c)$. Further, the lagged error term, Ect(-1) is negative and significant at 5 percent level. The coefficient of -0.80 indicates high rate of convergence to equilibrium.

As shown in Table 4 (see Appendix-III), the long-run estimates of the model show that capital formation (Gcf), skilled labor (Ser), foreign aid, and remittances (Remit) have positive and significant effects on welfare 


\section{Evans \& Kelikume}

$(G d p c)$. FDI, trade, and tourism are positive but insignificant. On the contrary, exchange rate (Excr), terrorism (Ter) and militancy (Mi) have negative and significant effects on welfare ( $G d p c)$. In a nutshell, this study establishes that, in the long-run, FDI, trade, and tourism have insignificant effects on welfare under terrorism and militancy.

The diagnostic tests are satisfactory. For both the short- and long-run models, the Breusch-PaganGodfrey Heteroskedasticity test suggests that the errors are homoscedastic and independent of the regressors, and also the Breusch-Godfrey Serial Correlation LM test shows that no autocorrelation exists in the error term.

Further, the stability of the long-run coefficients and short-run dynamics are examined. Consistent with Pesaran and Pesaran (1997), CUSUM tests are applied to the residuals of the model. "The Cumulative Sum (CUSUM) test makes use of the cumulative sum of recursive residuals based on the first set of $n$ observations and is updated recursively and plotted against break points. If the plot of CUSUM statistics stays within the critical bounds of 5 percent significance level..., the null hypothesis that all coefficients in the

error correction model are stable cannot be rejected. If either of the lines is crossed, the null hypothesis of coefficient constancy can be rejected at the 5 percent level of significance" (Tandrayen-Ragoobur, 2010: 16).

Figure 2 and 3 shows the graphs of the CUSUM tests. The plots of CUSUM are within 5 percent of critical bands. Since, the CUSUM plots do not cross the critical bounds, there is no evidence of any structural instability, meaning that the estimated short- and long-run models are stable. This gives credence to the fact that there exists short and long-run stability of the welfare model in Nigeria.

\section{DISCUSSION}

This study has filled an important gap in the literature. The study has delved into a neglected issue: the effects of FDI, trade, aid, remittances and tourism on welfare in Nigeria under terrorism and militancy. Although the effects of FDI, trade, aid, remittances and tourism on welfare has been studied in the past (e.g., Gomanee et al., 2003; Nowak et al., 2003; Yang and Martinez, 2005; Agarwal et al., 2010; Okodua and 
Alege, 2014; Evans, 2018), terrorism and militancy may have stirred a new set of behaviors and effects. This study is thus distinct from others in the literature in exploring the effects of terrorism and militancy on the effects of FDI, trade, aid, remittances and tourism on welfare.

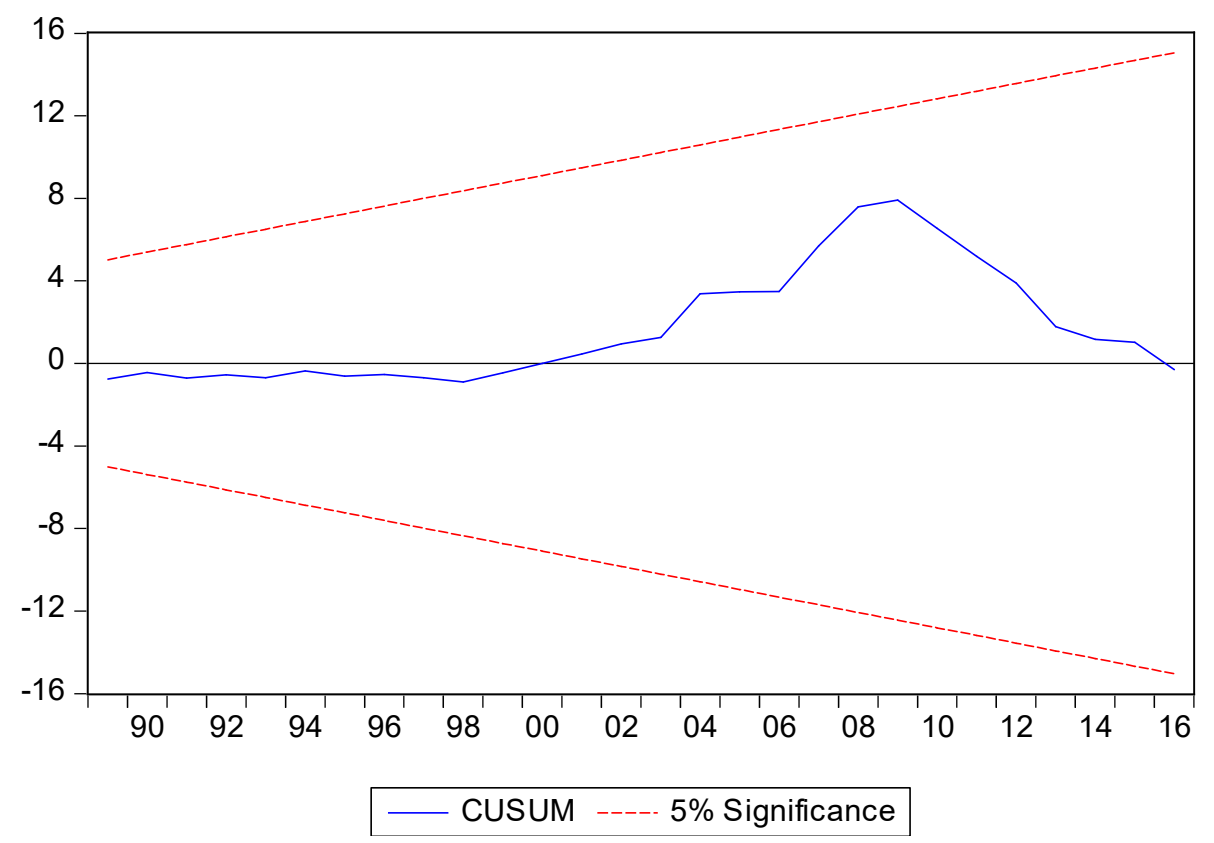

Figure 2. CUSUM Test for the Short-run Model

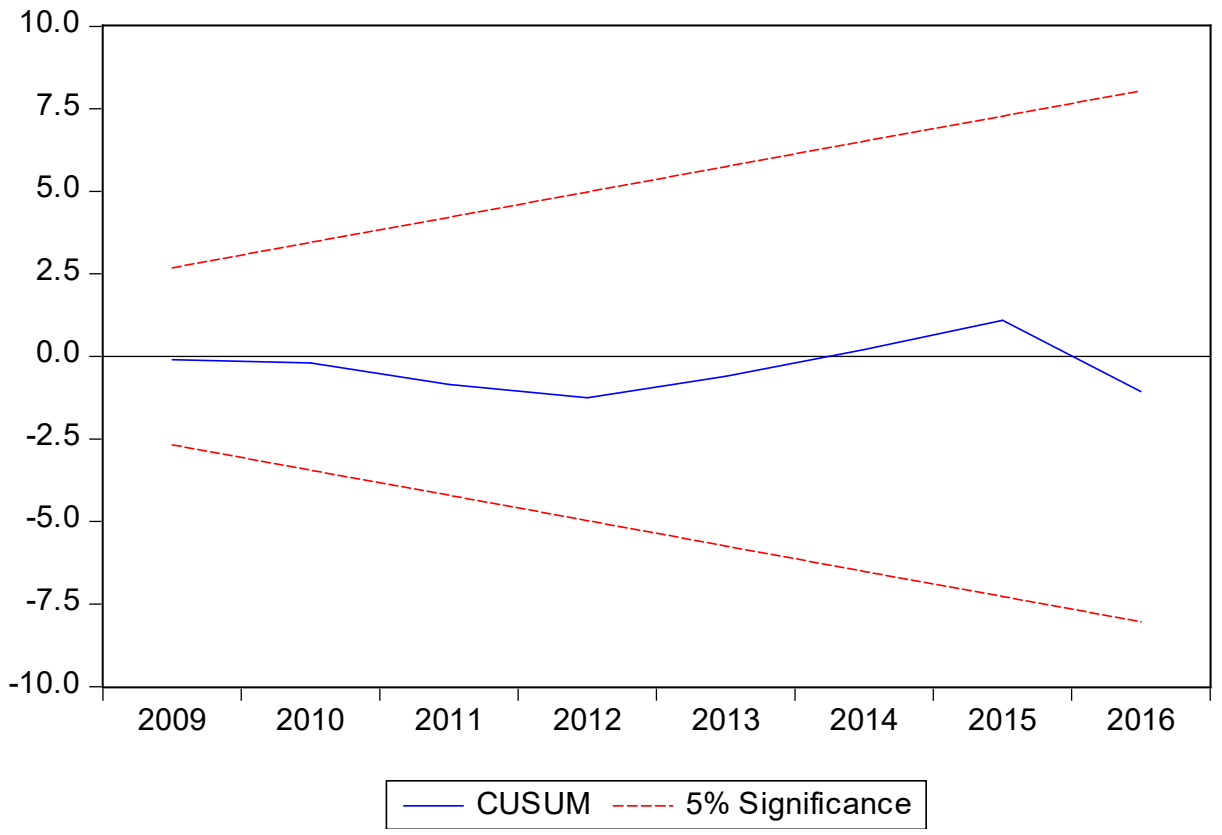

Figure 3. CUSUM Test for the Long-run Model 


\section{Evans \& Kelikume}

The path-breaking Harrod-Domar model $(1939,1946)$ stresses the importance of investment as a key determinant of output. As a result, Nigeria, like other developing countries, is open to international flows such as FDI, trade, aid, remittances and tourism in order to harness not only the growth effects but also the welfare benefits of such foreign flows (Okodua and Alege, 2014; Evans, 2018). In line with the HarrodDomar model, the current study has shown that foreign capital flows in form of FDI, trade, aid, remittances and tourism have positive significant effects on welfare in the short-run, even under terrorism and militancy. In developing countries such as Nigeria, lack of capital holds back growth and welfare. Boosting FDI, trade, aid, remittances and tourism generates foreign inflows which leads to a higher level of welfare.

Firstly, the finding that FDI has positive significant effects on welfare in the short-run is in line with the literature that showed that FDI augments capital formation in the host country and thereby promotes economic growth (e.g., Tang, Selvanathan and Selvanathan, 2008; Lean and Tan, 2011; Evans, 2018). However, the current study shows that FDI has insignificant effects on welfare in the long-run under terrorism and militancy. This finding is consistent with Bandyopadhyay et al. (2011) who showed that terrorism has a significantly adverse effect on FDI as a share of GDP. Evans (2018) also showed that the effect of FDI on welfare was repressed as a result of the presence of terrorism, militancy and policy uncertainty.

The finding that trade has positive significant effect on welfare in the short-run contrasts with Okodua and Alege (2014) who showed that a policy of full or partial trade liberalization has mixed welfare implications for Nigerian households in the short-run. Okodua and Alege (2014) actually showed that the policy will lead to increased consumption of goods and services as well as increased income for households, while at the same time hurting households by inducing unemployment in agriculture and industry. Beyond Okodua and Alege's (2014) findings, the current study shows that trade has positive significant effect on welfare in the short-run, but not in the long-run, as a result of militancy and terrorism.

The finding that aid has positive significant effect on welfare in the short- and long-run is consistent with Gomanee et al. (2003) who showed that aid is linked with improved welfare because aid finances pro-poor spending, meaning that aid can improve the welfare of the poor. However, Agarwal et al. (2010) showed that, under certain conditions, aid immiserizes the poor. Agarwal et al.'s (2010) finding may be connected to 
Burnside and Dollar's (2000) finding that aid has a positive effect on growth in developing countries with good policies but has insignificant effect in the presence of poor policies. Beyond these findings, present study shows that aid has positive significant effects on welfare in the short run and in the long-run, even under militancy and terrorism.

Further, the finding that remittance inflows have positive significant effect on welfare in the short and longrun is consistent with Lidley (2006) who showed that remittances inflows to a Somalian city improved their economic status and access to education. Adams and Page (2003) showed that remittances have a strong and statistically significant effect on poverty reduction in a sample of 74 low and middle-income developing countries. For Nigeria, Fonta et al. (2011) found that household poverty declines across all the Nigerian geopolitical zones, by sex and locality as a result of remittance inflows. The current study has also furthered the evidence that remittance inflows have positive significant effect on welfare in the short-run and in the long-run, even under militancy and terrorism.

Also, the finding that tourism has positive significant effects on welfare in the short run is consistent with Blake (2000) who showed that the effects of a 10 percent increase in tourism would be to increase welfare by 28 billion Pesetas ( $0.05 \%$ of GDP) over the long term in Spain. According to Gursoy et al. (2002), tourism development changes residents' quality of life. Beyond the existing findings, the current study has shown that tourism has positive significant effects on welfare in the short-run, but not in the long-run, as a result of militancy and terrorism.

The finding that terrorism and militancy have significant negative effects on welfare both in the short and long-run is consistent with Shah et al. (2016) who showed that the human cost of terror distorts private consumption, depresses investment as well as constrains growth both in the short and long-run. Beyond the existing findings in the literature, the current study shows that terrorism and militancy have likely undermined the effects of FDI, trade, remittances, aid and tourist flows on welfare.

\section{CONCLUSION}

This study investigates the effects of FDI, trade, aid, remittances and tourism on welfare in Nigeria under 


\section{Evans \& Kelikume}

terrorism and militancy. In the short-run, FDI, trade, aid, remittances and tourism have positive significant effects on welfare, even under terrorism and militancy. However, in the long-run, only aid and remittances have significant effects while FDI, trade and tourism were insignificant. In other words, FDI, trade and tourist inflows were repressed as a result of the presence of terrorism and militancy. FDI, trade and tourism cannot thrive in tensed and insecure environment. Despite militancy and terrorism, in the long run, aid and remittances still have significant effects on welfare. The findings also indicate that terrorism and militancy have significant negative effects on welfare in the short and long-run.

This study has filled an important gap in the literature. Although the effects of FDI, trade, aid, remittances and tourism on welfare have been studied in the past (e.g., Yang and Martinez, 2005; Okodua and Alege, 2014), this study is distinct from others in the literature in exploring the effects of terrorism and militancy in the relationships. While Harrod-Domar model $(1939,1946)$ stresses the importance of investment as a key determinant of output, in Nigeria, like other developing countries, lack of capital holds back growth and welfare. Therefore, in line with findings of this study, enhancing FDI, trade, aid, remittances and tourism can generate foreign inflows which may lead to higher levels of welfare.

However, this study has shown that the effects of foreign inflows such as FDI, trade and tourism on welfare were repressed as a result of the presence of terrorism and militancy. The implication is that foreign inflows such as FDI, trade and tourism cannot blossom in tensed and insecure environments. To encourage foreign inflows, it is important to curtail terrorism and militancy. The study has also shown that aid and remittances still have significant effects on welfare in the long-run despite militancy and terrorism. Therefore, aid and remittances can play particularly important roles in how people survive and recover in times of terrorism and militancy. The implication is that affected countries can continue to capitalize on foreign inflows in aid and remittances.

\section{IMPLICATIONS}

In line with the Harrod-Domar model, the current study has shown that FDI, trade, aid, remittances and tourism have positive significant effects on welfare in the short-run, even under terrorism and militancy. In capital-poor developing countries such as Nigeria, boosting foreign inflows such as FDI, trade, aid, 
remittances and tourism can lead to higher levels of welfare. The study has however shown that, in the longrun, only aid and remittances have significant effects while FDI, trade and tourism were insignificant. In other words, the effects of FDI, trade and tourist inflows on welfare were repressed as a result of the presence of terrorism and militancy. The implication is that FDI, trade and tourism cannot thrive in tensed and insecure environments (Osemwengie and Oriakhi, 2012). Investors and tourists are likely to become apprehensive and pull out or completely shun the affected country, which has severe implications for welfare. This finding is confirmed by the shutting down of Shell's Bonny oil facility; Chevron's Escravos GTL facility and ExxonMobil's Qua Iboe as a result of the February 2016 bombing on Shell pipeline. The outcome was drastic reduction in Nigerian oil production.

The findings also indicate that terrorism and militancy have significant negative effects on welfare both in the short- and long-run. This finding is confirmed by the shutting down of oil facilities and drastic reduction in Nigerian oil production. This finding is similarly confirmed by the Boko Haram attacks which have led to more than 2.6 million homeless people and 20,000 deaths. To curb the negative effects of terrorism and militancy on welfare, it is important to curtail terrorism and militancy. To this end, consolidated and concerted effort of Nigerian government at all levels would be crucial.

Additionally, if terrorism and militancy undermines FDI, trade and tourism in the country, welfare can be hampered. Terrorism and militancy would lead to the loss of foreign investors and tourists which would set in motion huge outflows of capital. Once the country is branded as a terrorist target, it would attract drastically reduced levels of FDI, trade and tourism. On this basis, the continual threats of terrorism and militancy can lead to economic costs in the form of low levels of FDI, trade, tourism and welfare. Policy efforts should therefore be geared towards reduction of terrorism and militancy so as to avert the possible economic costs to the country.

The empirical evidence has also provided some surprising findings that despite militancy and terrorism, in the long-run, aid and remittances still have significant impact on welfare. In the long-run, the country continues to receive billions of foreign currencies in remittances each year from its expatriates in diaspora. In the presence of militancy and terrorism, foreign workers still continue to transfer money to their home 


\section{Evans \& Kelikume}

country. During militant or terrorist attacks, remittances can therefore be a vital source of income for people whose other forms of livelihood may have been destroyed. Further, in the long-run, the country continues to receive aid from foreign governments. In the presence of militancy and terrorism, military aid continues to flow into the country as material or logistical assistance to strengthen military capabilities. During militant or terrorist attacks, emergency aid can serve as rapid assistance to people in immediate distress to relieve suffering.

In the long-run, therefore, countries affected by terrorism and militancy can use aid and remittances to supplement the low levels of FDI, trade and tourism. During militant or terrorist attacks, aid and remittances can play particularly important roles in how people survive and recover because they usually increase in times of crisis and directly contribute to household income. Thus, during such crises, affected countries can continue to capitalize on foreign currencies in remittances from its expatriates in diaspora. They can also capitalize on military aid to strengthen military capabilities and emergency aid to relieve suffering.

\section{LIMITATIONS AND FUTURE DIRECTIONS}

This study instigates important insights into the effects of FDI, trade, aid, remittances and tourism on welfare under terrorism and militancy from a developing country perspective. However, the study has a number of limitations which future studies can address. The fi ndings are based on a single-country analysis, suggesting that the results may not be generalizable, though likely to have applicability to other developing countries. Future research can therefore investigate the complex interfaces of FDI, trade, aid, remittances and tourism with terrorism and militancy, as well as with welfare in different countries/regions contexts. In the literature, there is no existing theory to explain the nature of the relationships between foreign inflows, terrorism/militancy/violence and welfare. There is therefore a need for a well-confirmed theory, made in a way consistent with scientific method, and described in such a way that studies should be able to provide empirical support for, or empirically contradict.

\section{REFERENCES}

Abonyi, S. E., \& Ezeh, C. I. (2017). Terrorism/insurgency and the welfare of the African child: The case of Boko Haram in Nigeria. International Journal of Social \& Management Sciences, Madonna University, 1(1): 84-90. 
Adams Jr, R. H., \& Page, J. (2003). Poverty, inequality and growth in selected Middle East and North Africa countries, 19802000. World Development, 31(12), 2027-2048.

Adeola, O., \& Evans, O. (2017). The impact of microfinance on financial inclusion in Nigeria. The Journal of Developing Areas, 51(4), 193-206.

Adeola, O., Boso, N., \& Evans, O. (2018). Drivers of international tourism demand in Africa. Business Economics, 53(1): 25-36.

Agarwal, M., Hazari, B. R., \& Xindun, L. (2010). Corruption, foreign aid and welfare to the poor. Journal of Economic Policy Reform, 13(4): 305-312.

Ajaero, C. K., Nzeadibe, C. T., Obisie-Nmehielle, N., \& Ike, C. C. (2018). The linkages between international migration, remittances and household welfare in Nigeria. Migration and Development, 7(1): 40-54.

Akinlo, A.E. (2004). Foreign Direct Investment and Growth in Nigeria an Empirical Investigation. Journal of Policy Modeling 26, 627-639.

Apergis, N., \& Cooray, A. (2018). Asymmetric real exchange rates and poverty: The role of remittances. Emerging Markets Review. 35(C): 111-119.

Arora, V. (2013). Alternative measures of welfare in macroeconomic models. Independent Statistics \& Analysis, Energy Information Administration, www.eia.gov U.S.

Bahadir, B., Chatterjee, S., \& Lebesmuehlbacher, T. (2018). The macroeconomic consequences of remittances. Journal of International Economics, 111, 214-232.

Bandyopadhyay, S., Sandler, T., \& Younas, J. (2011). Foreign direct investment, aid, and terrorism: An analysis of developing countries. Federal Reserve Bank of St. Louis Working Papers.

Bascom, W. O. (2016). The economics of financial reform in developing countries. Springer.

Behling, F. (2018). Trade Unions and the Challenge of Employee Welfare. In Welfare Beyond the Welfare State (pp. 235-261). Palgrave Macmillan: Cham.

Bentzen, J. \& Engsted, T., (2001). A revival of the autoregressive distributed lag model in estimating energy demand relationships. Energy, 26(1): 45-55.

Bhagwati, J. (2017). Trade liberalization among LDCs, trade theory, and GATT rules. In Value, Capital and Growth (pp. 21-44). Routledge.

Bhagwati, J. N. (2018). The Theory of Immiserizing Growth: Further Applications 1. In International trade and money (pp. 45-54). Routledge.

Blake, A. (2000). The economic effects of tourism in Spain. Christel DeHaan Tourism and Travel Research Institute.

Blanton, R. G., Early, B., \& Peksen, D. (2018). Out of the shadows or into the dark? Economic openness, IMF programs, and the growth of shadow economies. The Review of International Organizations, 13(2): 309-333.

Bolarinwa, J. O. (2018). International reactions and actions on militancy and insurgency in Nigeria since 1999. Insight on Africa, 10(1): 98-116.

Bunte, J. B., Desai, H., Gbala, K., Parks, B., \& Runfola, D. M. (2018). Natural resource sector FDI, government policy, and economic growth: Quasi-experimental evidence from Liberia. World Development, 107, 151-162.

Burnside, C., \& Dollar, D. (2000). Aid, policies, and growth. American economic review, 90(4): 847-868.

Carstensen, K., \& Toubal, F. (2004). Foreign direct investment in Central and Eastern European countries: a dynamic panel analysis. Journal of comparative economics, 32(1): 3-22.

Cobb, C. W., \& Douglas, P. H. (1928). A theory of production. The American Economic Review, 18(1): 139-165.

Cuong, N. V., \& Linh, V. H. (2018). The Impact of Migration and Remittances on Household Welfare: Evidence from Vietnam. Journal of International Migration and Integration, 1-19.

Dickey, D. A., \& Fuller, W. A. (1979). Distribution of the estimators for autoregressive time series with a unit root. Journal of The American Statistical Association, 74(366a), 427-431.

Djajić, S., (2006). Foreign aid, international migration and welfare. Frontiers of Economics and Globalization, 1, 105-115

Dollar, D., \& Kraay, A. (2003). Institutions, trade, and growth. Journal of Monetary Economics, 50(1): 133-162. 


\section{Evans \& Kelikume}

Domar, E. D. (1946). Capital expansion, rate of growth, and employment. Econometrica, Journal of the Econometric Society, 137-147.

Dreher, A., Lang, V., \& Ziaja, S. (2018). Foreign aid. The Oxford Handbook of Governance and Limited Statehood, 394.

Droogan, J. (2018). The perennial problem of terrorism and political violence in Pakistan. Journal of Policing, Intelligence and Counter Terrorism, 13(2): 202-215.

Duasa, J. (2007). Malaysian foreign direct investment and growth: does stability matter? Journal of Economic Cooperation, 28(2): 83-98.

Dzorgbo, D. B. S. (2017). Ghana in search of development: The challenge of governance, economic management and institution building. Routledge.

Ebenstein, A., Harrison, A., McMillan, M., \& Phillips, S. (2014). Estimating the impact of trade and offshoring on American workers using the current population surveys. Review of Economics and Statistics, 96(4): 581-595.

Enders, W., \& Sandler, T. (2008). Economic consequences of terrorism in developed and developing countries: An overview. In Keefer, P., Loayza, N. (Eds.), Terrorism, economic development and political openness. Cambridge University Press, New York, 17-47.

Evans O. (2018). The effects of FDI, domestic investment and infrastructure on welfare in Nigeria under terrorism, militancy and policy uncertainty, Business and Economic Quarterly, 4, 3-17.

Evans, O. (2017). Back to the land: The impact of financial inclusion on agriculture in Nigeria. Iranian Economic Review, 21(4): 885-903.

Fonta, W., Onyukwu, O., \& Nwosu, E. O. (2011). International remittance inflows and household welfare: empirical evidence from Nigeria. Research Journal of Finance and Accounting, 2(3): 140-149.

Frey, B.S., Luechinger, S., \& Stutzer, A. (2007). Calculating tragedy: Assessing the costs of terrorism. Journal of Economic Surveys, 21(1): $1-24$

Ganaie, N. A. (2018). Modernizing extremism: A case of new age militancy in Kashmir. Advances in Politics and Economics, 1(1): 6168.

Ghatak, S., \& Siddiki, J. U., (2001). The use of the ARDL approach in estimating virtual exchange rates in India. Journal of Applied statistics, 28(5): 573-583.

Gomanee, K., Morrissey, O., Mosley, P., \& Verschoor, A. (2003). Aid, pro-poor government spending and welfare. Centre for Research in Economic Development and International Trade, University of Nottingham, Working Paper. No. 03/03.

Greenaway, D., Morgan, W., \& Wright, P. (2002). Trade liberalisation and growth in developing countries. Journal of Development Economics, 67(1): 229-244.

Grossman, G. M., \& Helpman, E. (2018). Growth, trade, and inequality. Econometrica, 86(1): 37-83.

Gunby, P., Jin, Y., \& Reed, W. R. (2017). Did FDI really cause Chinese economic growth? A meta-analysis. World Development, 90, 242-255.

Gupta, M. R., \& Dutta, P. B. (2018). Tourism development, environmental pollution and economic growth: A theoretical analysis. The Journal of International Trade and Economic Development, 27(2): 125-144.

Gursoy, D., Jurowski, C., \& Uysal, M. (2002). Resident attitudes. A structural modelling approach. Annals of Tourism Research, 29(1): 79105.

Haggard, S., \& Kaufman, R. R. (2018). The politics of economic adjustment: international constraints, distributive conflicts and the state. Princeton University Press.

Harrod, R. F. (1939). An essay in dynamic theory. The Economic Journal, 49(193): 14-33.

Höhne-Sparborth, T. (2018). The socio-economic spill-over effects of armed conflict on neighbouring countries (Doctoral dissertation, The London School of Economics and Political Science (LSE).

Kangmennaang, J., Bezner-Kerr, R., \& Luginaah, I. (2018). Impact of migration and remittances on household welfare among rural households in Northern and Central Malawi. Migration and Development, 7(1): 55-71.

Klobodu, E. K. M., \& Adams, S. (2016). Capital flows and economic growth in Ghana. Journal of African Business, 17(3): $291-307$. 
Lawn, P. A. (2003). A theoretical foundation to support the Index of Sustainable Economic Welfare (ISEW), Genuine Progress Indicator (GPI), and other related indexes. Ecological Economics, 44(1): 105-118.

Lean, H. H., \& Tan, B. W. (2011). Linkages between foreign direct investment, domestic investment and economic growth in Malaysia. Journal of Economic Cooperation and Development, 32(4): 75-96.

Li, X., \& Wang, D. (2017). The impacts of rural- urban migrants' remittances on the urban economy. In Labor Transfer in Emerging Economies (pp. 97-110). Singapore: Springer.

Liang, F. H. (2017). Does foreign direct investment improve the productivity of domestic firms? Technology spillovers, industry linkages, and firm capabilities. Research Policy, 46(1): 138-159.

Lindley, A. (2007). Remittances in fragile settings: A Somali case study. Households in Conflict Network, The Institute of Development Studies - at the University of Sussex - Falmer - Brighton - BN1 9RE, www.hicn.org

Magombeyi, M. T., \& Odhiambo, N. M. (2017). Foreign direct investment and poverty reduction. Comparative Economic Research, 20(2): 73-89.

Manuelli, R. (2017). Natural Disasters and Growth: The Role of Foreign Aid and Disaster Insurance. In 2017 Meeting Papers (No. 1118). Society for Economic Dynamics. 1-32. https://sites.wustl.edu/rodymanuellifiles/2017/06/NatDisasters_Growth_Apr23_20171nxlcgq.pdf

Melane-Lavado, A., Álvarez-Herranz, A., \& González-González, I. (2018). Foreign direct investment as a way to guide the innovative process towards sustainability. Journal of Cleaner Production, 172, 3578-3590.

Nelson, C. R., \& Plosser, C. R. (1982). Trends and random walks in macroeconmic time series: some evidence and implications. Journal of Monetary Economics, 10(2): 139-162.

Njinyah, S. Z. (2018). The effectiveness of government policies for export promotion on the export performance of SMEs Cocoa exporters in Cameroon. International Marketing Review, 35(1): 164-185.

Njoya, E. T., \& Seetaram, N. (2018). Tourism contribution to poverty alleviation in Kenya: A dynamic computable general equilibrium analysis. Journal of Travel Research, 57(4): 513-524.

Noorbakhsh, F., Paloni, A., \& Youssef, A. (2001). Human capital and FDI inflows to developing countries: New empirical evidence. World Development, 29(9): 1593-1610.

Nowak, J. J., Sahli, M., \& Sgro, P. M. (2003). Tourism, trade and domestic welfare. Pacific Economic Review, 8(3): 245-258.

Ogbozor, E. N. (2018). The impact of violent extremism on rural livelihoods in the Lake Chad Basin (Doctoral dissertation, George Mason University).

Okodua, H., \& Alege, P. O. (2014). Household welfare impact of trade liberalization in Nigeria: A computable general equilibrium model. Journal of Economics and Sustainable Development, 5(28): 41-52.

Olagbaju, I. O., \& Akinlo, A. E. (2018). FDI And Economic Growth Relationship In Sub-Saharan Africa: Is The Domestic Financial System A Significant Intermediator? Archives of Business Research, 6(5): 90-112.

Ordu, G. E. O. (2017). Trends and patterns of Boko Haram terrorist and militants' aggression in Nigeria. Aggression and Violent Behavior. 37, 35-41

Osemwengie, D. O. P., \& Oriakhi, D. E. (2012). The Impact of National Security on Foreign Direct Investment in Nigeria: An Empirical Analysis. Journal of Economics and Sustainable Development, 3(13): 88-96.

Perkins, R., Castaño, M. C., \& Montemayor, C. (2018). Analysis of predictability and accountability transparency practices and FTA on trade growth in selected countries of the Asia-Pacific region: A descriptive-causal approach. Journal of Economic Structures, 7(1): 10-19.

Pesaran, H. M and B. Pesaran (1997). Working with Microfit 4.0: Interactive economteric analysis. London: Oxford University Press.

Pesaran, M. H., Shin, Y., \& Smith, R. P. (1999). Pooled mean group estimation of dynamic heterogeneous panels. Journal of the American Statistical Association, 94(446): 621-634.

Pesaran, M. H., Shin, Y., \& Smith, R. J., (2001). Bounds testing approaches to the analysis of level relationships. Journal of Applied Econometrics, 16(3): 289-326. 


\section{Evans \& Kelikume}

Peterson, A. (2001). Contemporary political protest: Essays on political militancy. Ashgate Pub Limited.

Petreski, B., Tumanoska, D., Dávalos, J., \& Petreski, M. (2018). New Light on the Remittances- Poverty- Health Nexus in Macedonia. International Migration. 56(6): 3-16

Phillips, P. C., \& Perron, P. (1988). Testing for a unit root in time series regression. Biometrika, 75(2): 335-346.

Picciotto, S., \& Mayne, R. (Eds.). (2016). Regulating international business: Beyond liberalization. Springer.

Pigou, A. (2017). The economics of welfare. Routledge.

Raza, S. A., \& Shah, N. (2017). Tourism growth and income inequality: does Kuznets Curve hypothesis exist in top tourist arrival countries. Asia Pacific Journal of Tourism Research, 22(8): 874-884.

Reis, A. B. (2001). On the welfare effects of foreign investment. Journal of International Economics, 54(2): 411-427.

Saeed, L., \& Syed, S. H. (2018). Causal linkages between terrorism and economic growth: Evidence from the four provinces of Pakistan. Peace Economics, Peace Science and Public Policy, 24(1): 117-124

Salacuse, J. W. (2017). BIT by BIT: The growth of bilateral investment treaties and their impact on foreign investment in developing countries. In Globalization and International Investment (pp. 25-45). Routledge.

Savun, B., \& Tirone, D. C. (2017). Foreign Aid as a Counterterrorism Tool: More Liberty, Less Terror? Journal of Conflict Resolution, 62(8): 1607-1635.

Seteolu, D. (2017). Issues and perspectives on Nigeria's international economic relations. International Relations, 5(4): $225-232$.

Shah, S. H., Hasnat, H., \& Ahmad, M. H. (2016). The effects of the human cost of terror on national income, private consumption and investment in Pakistan: An empirical analysis. South Asia Economic Journal, 17(2): 216-235.

Shalev, M. (2018). Liberalization and the transformation of the political economy. In The New /srae/(pp. 129-159). Routledge.

Sharma, A., Rishad, A., \& Gupta, S. (2018). Relationship Between Fdi, Export and Economic Growth In India: Evidence From Toda And Yamamoto Approach. Journal of Academic Research in Economics, 10(1): 4-15.

Siddique, H. M. A., Ansar, R., Naeem, M. M., \& Yaqoob, S. (2017). Impact of FDI on economic growth: Evidence from Pakistan. Bulletin of Business and Economics, 6(3): 111-116.

Sirgy, M. J., Joshanloo, M., \& Estes, R. J. (2018). The global challenge of jihadist terrorism: A quality-of-life model. Social Indicators Research, 140, 1-25.

Stankov, L., Knežević, G., Saucier, G., Radović, B., \& Milovanović, B. (2018). Militant extremist mindset and the assessment of radicalization in the general population. Journal of Individual Differences. 39, 88-98

Tandrayen-Ragoobur, V. (2010). The services sector and economic growth in Mauritius. A bounds testing approach to Co-intergration. University of Mauritius Research Journal, 16(1): 313-331.

Tang, S., Selvanathan, E. A., \& Selvanathan, S. (2008). Foreign direct investment, domestic investment and economic growth in China: A time series analysis. The World Economy, 31(10): 1292-1309.

Theodorou, P. (2017). World trade organization and stimulating innovation: An outline approach towards growth in the Chinese market. In Global opportunities for entrepreneurial growth: Coopetition and knowledge dynamics within and across firms (pp.441-452) Emerald Publishing Limited.

Urtasun, A., \& Gutiérrez, I. (2006). Tourism agglomeration and its impact on social welfare: An empirical approach to the Spanish case. Tourism Management, 27(5): 901-912.

Wacziarg, R., \& Welch, K. H. (2008). Trade liberalization and growth: New evidence. The World Bank Economic Review, 22(2): 187231.

Wadood, S. N., \& Hossain, A. (2017). Microeconomic impact of remittances on household welfare: Evidences from Bangladesh. Business and Economic Horizons, 13(1): 10-29.

Wang, M. (2009). Manufacturing FDI and economic growth: Evidence from Asian economies. Applied Economics, 41(8): 991-1002.

Wardana, I. M., Adnyani, I. G. A. D., \& Ekawati, N. I. W. (2017). Economic impact of tourism, welfare material, personal benefits, and life satisfaction of local residents. International Journal of Research in Commerce, Economics and Management, 7(3), 1-6.

World Bank (2018) World Development Indicators. http://databank.worldbank.org/data/reports.aspx?source=world-developmentindicators

Yang, D., \& Martinez, C. (2006). Remittances and poverty in migrants' home areas: Evidence from the Philippines . International 
International Journal of Management, Economics and Social Sciences

migration, remittances and the brain drain. Washington DC: World Bank, 81-121.

Zhang, J., \& Zhang, Y. (2018). Carbon tax, tourism $\mathrm{CO}_{2}$ emissions and economic welfare. Annals of Tourism Research, 69, 18-30. 


\section{Evans \& Kelikume}

Appendix-I

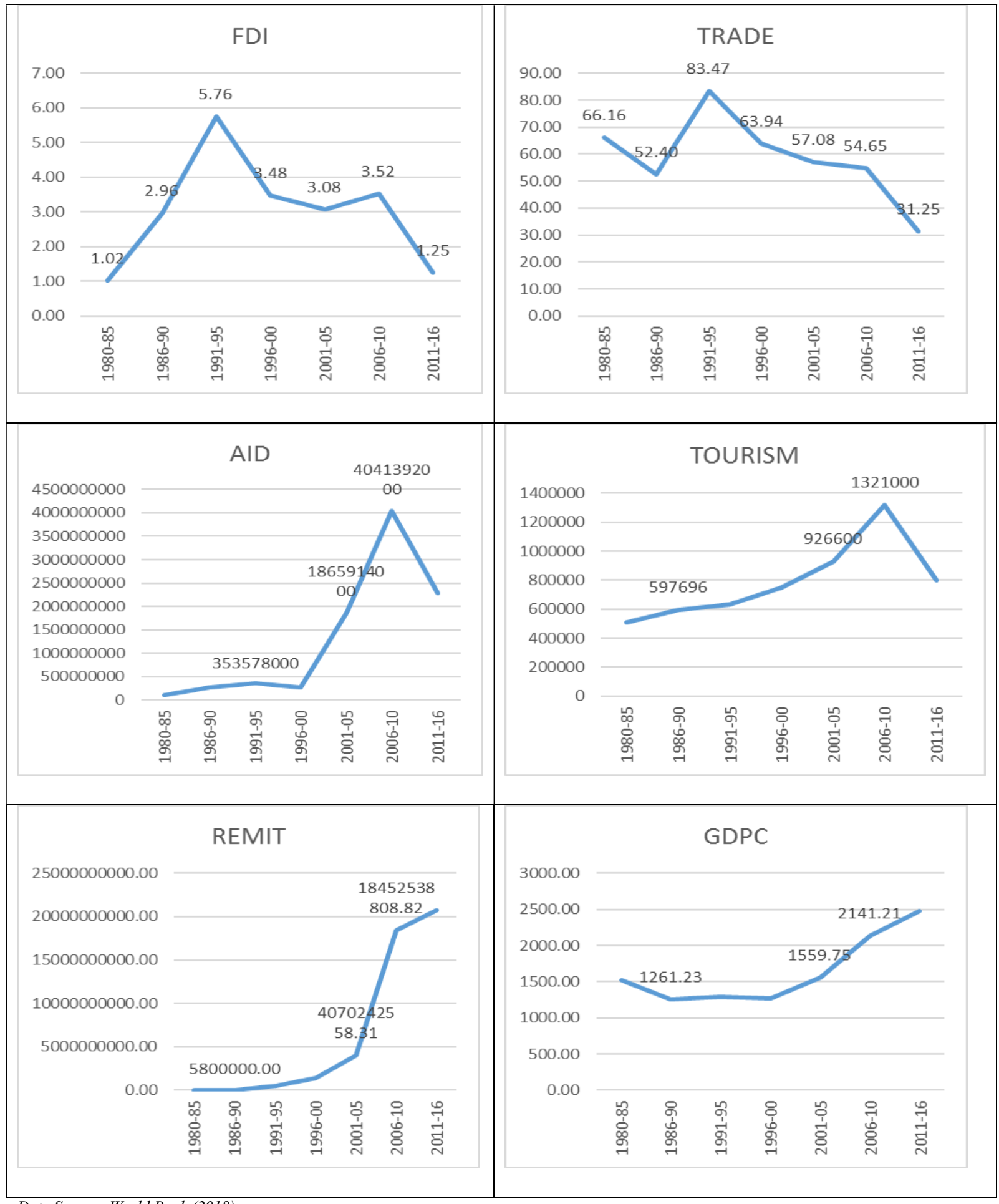

Data Source: World Bank (2018)

Figure 1. Trends of FDI, Trade Openness, Aid, Remittances, Tourism and GDP Per Capita 
Dependent Variable: $\Delta(G d p c)$

\begin{tabular}{|c|c|c|c|c|}
\hline Variable & Coefficient & Std. Error & $t$-Statistic & Prob. \\
\hline$\Delta(G d p c(-1))$ & $1.32 * *$ & 0.08 & 16.39 & 0.04 \\
\hline$\Delta(G c f)$ & -0.78 & 0.15 & -5.30 & 0.12 \\
\hline$\Delta(G c f(-1))$ & $1.44 * *$ & 0.08 & 17.60 & 0.04 \\
\hline$\Delta(\mathrm{Ser})$ & $2.39 * *$ & 0.12 & 19.40 & 0.03 \\
\hline$\Delta(\operatorname{Ser}(-1))$ & $3.21 * * *$ & 0.26 & 12.51 & 0.05 \\
\hline$\Delta(F d i)$ & 0.26 & 0.16 & 1.61 & 0.35 \\
\hline$\Delta(F d i(-1))$ & $0.84 * * *$ & 0.09 & 9.67 & 0.07 \\
\hline$\Delta($ Trade $)$ & $0.22 * * *$ & 0.02 & 11.37 & 0.06 \\
\hline$\Delta(\operatorname{Trade}(-1))$ & $0.42 * * *$ & 0.03 & 12.31 & 0.05 \\
\hline$\Delta($ Aid $)$ & $1.45 * * *$ & 0.13 & 11.18 & 0.06 \\
\hline$\Delta(\operatorname{Aid}(-1))$ & $2.64 * * *$ & 0.24 & 10.98 & 0.06 \\
\hline$\Delta$ (Remit) & -0.18 & 0.07 & -2.38 & 0.25 \\
\hline$\Delta(\operatorname{Remit}(-1))$ & $1.09 * *$ & 0.06 & 16.94 & 0.04 \\
\hline$\Delta$ (Tourism) & $1.19^{* *}$ & 0.08 & 14.93 & 0.04 \\
\hline$\Delta($ Tourism $(-1))$ & $1.87 * *$ & 0.11 & 16.23 & 0.04 \\
\hline$\Delta($ Excr $)$ & -1.44 & 0.22 & -6.54 & 0.10 \\
\hline$\Delta(\operatorname{Excr}(-1))$ & $-5.38 * * *$ & 0.41 & -13.11 & 0.05 \\
\hline$\Delta($ Ter $)$ & $-2.64 * * *$ & 0.29 & -9.19 & 0.07 \\
\hline$\Delta(\operatorname{Ter}(-1))$ & $-0.26 * * *$ & 0.03 & -8.05 & 0.08 \\
\hline$\Delta(\mathrm{Mil})$ & $-0.11 * * *$ & 0.01 & -10.06 & 0.06 \\
\hline$\Delta(\operatorname{Mil}(-1))$ & $-1.16 * * *$ & 0.09 & -12.74 & 0.05 \\
\hline \multirow[t]{3}{*}{$\operatorname{Ect}(-1)$} & $-0.80 * *$ & 0.05 & -15.07 & 0.04 \\
\hline & R-squared & 0.94 & $\begin{array}{ll}\text { Breusch-Godfrey } & \text { Serial } \\
\text { Correlation LM Test: } & \end{array}$ & 5.68 \\
\hline & Adjusted R-squared & 0.93 & $\begin{array}{l}\text { Breusch-Pagan-Godfrey } \\
\text { Heteroskedasticity Test }\end{array}$ & 1.5 \\
\hline
\end{tabular}

Table 3. Short Run Estimates 


\section{Evans \& Kelikume}

Appendix-III

Dependent Variable: $G d p c$

\begin{tabular}{|c|c|c|c|c|c|c|}
\hline Variable & Coefficient & & $\begin{array}{l}\text { Std. } \\
\text { Error }\end{array}$ & $t$-Statistic & & Prob. \\
\hline$G c f$ & $1.16^{*}$ & & 0.23 & 4.98 & & 0.00 \\
\hline $\mathrm{Ser}$ & $0.65 * *$ & & 0.29 & 2.22 & & 0.04 \\
\hline$F d i$ & 0.93 & & 0.66 & 1.41 & & 0.17 \\
\hline Trade & 0.16 & & 0.10 & 1.51 & & 0.14 \\
\hline Aid & $0.00 * * *$ & & 0.00 & 1.88 & & 0.07 \\
\hline Remit & $1.33 * *$ & & 0.61 & 2.17 & & 0.04 \\
\hline Tourism & 3.53 & & 4.93 & 0.72 & & 0.48 \\
\hline Excr & $-0.02 * *$ & & 0.01 & -2.67 & & 0.01 \\
\hline Ter & $-13.28 * * *$ & & 6.64 & -2.00 & & 0.06 \\
\hline Mil & $-0.22 * *$ & & 0.09 & -2.45 & & 0.02 \\
\hline \multirow[t]{3}{*}{ C } & $6.06^{*}$ & & 0.61 & 9.96 & & 0.00 \\
\hline & R-squared & & 0.97 & $\begin{array}{l}\text { Breusch-Godfrey } \\
\text { Correlation LM Test: }\end{array}$ & Serial & 2.09 \\
\hline & $\begin{array}{l}\text { Adjusted } \\
\text { squared }\end{array}$ & R- & 0.96 & $\begin{array}{l}\text { Breusch-Pagan-Godfrey } \\
\text { Heteroskedasticity Test }\end{array}$ & & 1.17 \\
\hline
\end{tabular}

Table 4. Long Run Estimates 